\title{
PENERAPAN STANDAR MUTU PADA PENANGANAN IKAN CAKALANG (Katsuwonus pelamis) DI PPP PONDOKDADAP KABUPATEN MALANG
}

\author{
APPLICATION OF QUALITY STANDARDS ON SKIPJACK \\ (Katsuwonus pelamis) HANDLING PRACTICES \\ AT PPP PONDOKDADAP MALANG
}

\author{
Jalal Sayuti, Mario Limbong \\ Jl. Arteri Pondok Indah No. 11 Kebayoran Lama - Jakarta Selatan \\ Fakultas Perikanan dan Ilmu Kelautan, Universitas Satya Negara Indonesia
}

\begin{abstract}
ABSTRAK
Pelabuhan perikanan merupakan salah satu prasarana penting dalam pengembangan perikanan khususnya perikanan tangkap sehingga dapat lebih meningkatkan pemanfaatan potensi perikanan laut agar optimal. Penelitian ini bertujuan untuk: (1) Mengetahui jumlah ikan cakalang (Katsuwonus pelamis) yang didaratkan di PPP Pondokdadap yang memenuhi standar mutu. (2) Mengetahui cara penanganan ikan cakalang (Katsuwonus pelamis) mulai dari tempat pendaratan ikan, tempat supplier ikan dan tempat pemasaran ikan di PPP Pondokdadap. (3) Menganalisis tingkat penerapan standar mutu penanganan ikan cakalang (Katsuwonus pelamis) di PPP Pondokdadap. Total jumlah hasil tangkapan ikan cakalang dalam 1 tahun di PPP Pondokdadap diketahui persentase jumlah hasil tangkapan dengan mutu 2 (dua) sebanyak 19\% dari total jumlah hasil tangkapan. Hal ini menunjukkan bahwa di PPP Pondokdadap memiliki hasil tangkapan ikan cakalang dengan mutu yang baik. Jumlah ikan cakalang yang didaratkan di PPP Pondokdadap tahun 2018 dibagi dalam 3 kategori yaitu ikan mutu 1, ikan mutu 2 dan ikan cakalang kecil, dengan persentase ikan mutu 1 sebanyak 62\%, ikan mutu 2 sebanyak 19\% dan ikan cakalang kecil sebanyak 19\% dan tingkat losses sebesar 3,23\% selama 1 tahun. Berdasarkan hasil perhitungan tingkat kehilangan akibat susut mutu (losses) ikan cakalang di PPP Pondokdadap didapatkan rata-rata tingkat losses sebesar 3,23\% dalam 1 tahun. Berdasarkan hasil analisis tingkat kesesuaian penanganan ikan cakalang yang saat ini dilakukan di Tempat Pendaratan Ikan PPP Pondokdadap didapatkan kesenjangan sebesar 1,5 dengan tingkat kesesuaian yaitu sebesar 62,5\% yang berarti penanganan tersebut kurang sesuai dengan standar. Hal ini menunjukkan bahwa ikan cakalang yang didaratkan di PPP Pondokdadap memiliki mutu yang baik. Proses penanganan ikan cakalang di tempat pendaratan ikan, tempat pengumpul ikan dan kios ikan nelayan sudah cukup baik namun masih harus diperbaiki lagi khususnya dari aspek sanitasi dan higene bangunan, karyawan dan peralatan. Tingkat penerapan standar mutu penanganan ikan cakalang di tempat pendaratan ikan rata-rata mencapai 62,5\%, tingkat penerapan standar mutu di tempat pengumpul ikan ratarata mencapai $67,2 \%$ dan tingkat penerapan standar mutu di kios ikan nelayan rata-rata mencapai $73,2 \%$.
\end{abstract}




\section{PENDAHULUAN}

Menurut Peraturan Menteri Kelautan dan Perikanan Nomor: 08/MEN/2012, Pelabuhan Perikanan merupakan tempat yang terdiri atas daratan dan perairan di sekitarnya dengan batas-batas tertentu sebagai tempat kegiatan pemerintahan dan kegiatan sistem bisnis perikanan yang digunakan sebagai tempat kapal perikanan bersandar, berlabuh, dan/atau bongkar muat ikan yang dilengkapi dengan fasilitas keselamatan pelayaran dan kegiatan penunjang perikanan. Penanganan hasil tangkapan dimulai dari setelah hasil tangkapan tiba di atas kapal sampai dengan hasil tangkapan didistribusikan, karena proses perubahan mutu hasil tangkapan telah terjadi sejak ikan selesai ditangkap sampai didistribusikan. Ikan ditempatkan di palka kapal, sesampainya di pelabuhan selanjutnya dikeluarkan ke dek sampai dermaga bongkar kemudian dari dermaga tersebut diangkut menuju ke tempat pelelangan ikan (TPI) dan seterusnya sampai pendistribusian ke konsumen. Pemilihan PPP Pondokdadap sebagai lokasi penelitian karena PPP Pondokdadap merupakan salah satu pelabuhan yang menjadi prioritas untuk dikembangkan. Hal ini karena potensi ikan hasil tangkapan khususnya ikan cakalang di PPP Pondokdadap masih layak untuk dikembangkan lebih lanjut. Pada tahun 2017, Kementerian Kelautan dan Perikanan sudah mengeluarkan anggaran lebih dari 30 milyar rupiah untuk membangun sarana dan prasarana di PPP Pondokdadap.

Pembangunan sarana dan prasarana ini bertujuan agar produk ikan hasil tangkapan di PPP Pondokdadap memiliki mutu yang bagus sehingga harganya lebih tinggi dibanding ikan dari pelabuhan lain. Atas dasar permasalahan di atas, penelitian untuk mengetahui sejauh mana penerapan standar mutu pada penanganan ikan cakalang (Katsuwonus pelamis) mulai dari tempat pendaratan ikan, gudang supplier/pengumpul dan kios ikan nelayan di PPP Pondokdadap sesuai dengan Keputusan Menteri Kelautan dan Perikanan Nomor: 52A Tahun 2013 tentang Persyaratan Jaminan Mutu dan Keamanan Hasil Perikanan Pada Proses Produksi, Pengolahan dan Distribusi penting untuk segera dilakukan. Berdasarkan rumusan masalah di atas, maka tujuan dari penelitian ini adalah untuk mengetahui jumlah ikan cakalang (Katsuwonus pelamis) yang didaratkan di PPP Pondokdadap yang memenuhi standar mutu, mengetahui cara penanganan ikan cakalang (Katsuwonus pelamis) mulai dari tempat pendaratan ikan, tempat 
supplier ikan dan tempat pemasaran ikan di PPP Pondokdadap, dan menganalisis tingkat penerapan standar mutu penanganan ikan cakalang (Katsuwonus pelamis) di PPP Pondokdadap.

\section{METODE PENELITIAN}

Penelitian dengan judul "Penerapan Standar Mutu Pada Penanganan Ikan Cakalang (Katsuwonus pelamis) di PPP Pondokdadap Kabupaten Malang”, dilaksanakan pada bulan November 2018 - Januari 2019 bertempat di PPP Pondokdadap Kabupaten Malang, Jawa Timur. Penelitian ini menggunakan metode deskriptif komparatif yang berfungsi untuk membandingkan penanganan ikan hasil tangkapan di PPP Pondokdadap saat ini dengan standar penanganan yang seharusnya dan metode survei yaitu pengamatan atau observasi langsung di lapangan. Sampel diambil dari tiga lokasi yaitu tempat pendaratan ikan, gudang supplier/pengumpul dan kios ikan nelayan untuk penilaian organoleptik selama bulan November - Desember 2018 secara random sampling masing-masing 6 (enam) ekor per lokasi atau per titik yaitu TPI, gudang supplier dan kios ikan nelayan. Pengambilan sampel dilakukan selama 4 (empat) kali sehingga jumlah sampel yang diambil 72 ekor ikan cakalang untuk uji organoleptik dan pengujiannya dilakukan oleh 6 orang panelis standar.

Analisis dilakukan secara deskriptif terhadap jumlah ikan cakalang yang didaratkan di Tempat Pendaratan Ikan. Analisis dilakukan dengan mengelompokkan data produksi selama 1 (satu) tahun. Pengelompokan data berdasarkan ukuran (size) dan mutu ikan cakalang. Pengelompokan ukuran (size) dibedakan menjadi 2 (dua) yaitu cakalang besar dengan ukuran diatas 200 gr/ekor dan cakalang kecil dengan ukuran dibawah 200gr/ekor. Dari kelompok ikan cakalang besar dikelompokkan lagi berdasarkan mutunya. Mutu ikan cakalang di PPP Pondokdadap dikelompokkan menjadi 2 (dua) kelompok yaitu mutu 1 (satu) dan mutu 2 (dua). Dari perbedaan mutu tersebut dihitung tingkat kehilangan (losses) susut mutu berdasarkan perbedaan harga. Menurut Wibowo (2014), tingkat losses tersebut dihitung dengan formula sebagai berikut: 


$$
\frac{\left(B_{T} \times H_{1}\right)-\left(B_{1} \times H_{1}\right)+\left(B_{2} \times H_{2}\right)}{\left(B_{T} \times H_{1}\right)} \times 100 \%
$$

Keterangan: $B_{T}:$ Berat Total $(\mathrm{kg})$

$H_{1}$ : Harga Mutu 1 (rupiah)

$B_{1}$ : Berat Ikan Mutu $1(\mathrm{~kg})$

$B_{2}$ : Berat Ikan Mutu $2(\mathrm{~kg})$

$\mathrm{H}_{2}$ : Harga Mutu 2 (rupiah)

Analisis deskriptif dilakukan dengan mengamati penanganan ikan cakalang di tempat pendaratan ikan, gudang supplier/pengumpul dan kios ikan nelayan dengan beberapa parameter yaitu tahapan penanganan, suhu ikan saat penanganan, kondisi sanitasi dan higiene dan lainnya. Analisis juga dilengkapi uji organoleptik yang dilakukan dengan uji scoring test yaitu metode uji dalam menentukan tingkat kesegaran mutu ikan berdasarkan skala angka 1 (satu) sebagai nilai terendah dan angka 9 (sembilan) sebagai nilai tertinggi dengan menggunakan lembar penilaian (score sheet). Metode pengujian berdasarkan SNI 2346:2011. Cara uji organoleptik dilakukan dengan prosedur sebagai berikut:

- Contoh merupakan produk segar dan menghindari kontak langsung dengan air, misalnya membungkus produk dalam plastik.

- Penyajian contoh dalam wadah minimal untuk 6 orang panelis dan diberi kode sesuai jenis ikan dan titik pengambilan.

- Menyiapkan contoh dan lembar penilaian (score sheet) dalam bilik pengujian.

- Panelis melakukan pengujian dengan memberikan nilai pada lembar penilaian sesuai tingkatan mutu produk yang diuji.

- Setelah selesai lembar pengujian dikumpulkan.

Analisis gap digunakan untuk menilai seberapa besar kesenjangan antara penanganan ikan cakalang di PPP Pondokdadap saat ini dengan penanganan standar yang telah ditetapkan dalam KEPMEN-KP 52A tahun 2013 Tentang Persyaratan Jaminan Mutu dan Keamanan Hasil Perikanan pada Proses Produksi, Pengolahan dan Distribusi. Semakin besar nilai gap suatu atribut 
maka tingkat kesesuaiannya semakin rendah. Menurut Palan (2007), Gap dihitung berdasarkan formula sebagai berikut:

$$
\text { Gap = Penanganan Standar - Penanganan saat ini }
$$

Selanjutnya dilakukan analisis kesenjangan (gap) seperti terlihat pada rumus (1) dan selanjutnya analisis tingkat kesesuaian seperti terlihat pada rumus (2) sebagai berikut:

Kesenjangan $($ gap $)=(C L r-C L h) \ldots(1)$

Tingkat Kesesuaian $=(x \bar{C} L \mathrm{~h}) /(\overline{x C} L r) \times 100 \% \ldots(2)$

Keterangan:

CLr : Nilai maksimum yang dapat diperoleh yaitu 4 (empat)

CLh : Nilai penanganan saat ini (nilai yang diperoleh dari hasil penilaian terhadap aspek penanganan ikan cakalang di PPP Pondokdadap).

Penanganan saat ini berupa nilai kuantitatif yang dihitung dari hasil kuesioner, sedangkan penanganan standar adalah standar yang telah ditetapkan melalui KEPMEN-KP 52A tahun 2013. Penentuan nilai kesenjangan dibuat selang frekuensi berdasarkan data tingkat kesesuaian dan selisih nilai. Analisis gap dalam penanganan ikan cakalang di PPP Pondokdadap meliputi beberapa tahap yaitu:

1) Mengidentifikasi aspek-aspek sistem penanganan ikan cakalang.

2) Melakukan penilaian terhadap aspek-aspek. Penentuan nilai kesenjangan dibuat selang frekuensi berdasarkan data tingkat kesesuaian dan selisih nilai. Dalam penelitian ini digunakan 5 selang frekuensi (0-4).

3) Pengambilan keputusan kesenjangan penanganan ikan cakalang di PPP Pondokdadap berdasarkan kriteria berikut:

$0 \% \quad-\leq 35 \% \quad$ : Penanganan sangat tidak sesuai standar

$35 \%-\leq 50 \%$ : Penanganan tidak sesuai standar

$50 \% \quad-\leq 65 \% \quad$ : Penanganan kurang sesuai standar

$65 \%-\leq 80 \%$ : Penanganan hampir sesuai standar

$80 \%-\leq 100 \%$ : Penanganan sesuai dengan standar 


\section{HASIL DAN PEMBAHASAN}

Hasil tangkapan ikan cakalang yang didaratkan di PPP Pondokdadap berasal dari kapal - kapal penangkapan yang menggunakan alat tangkap pancing ulur atau pancing tonda. Jumlah ikan cakalang yang didaratkan selama tahun 2018 sebanyak $3.721 .652 \mathrm{~kg}$ dengan komposisi ikan cakalang mutu 1 sebanyak 2.326.600 kg, ikan cakalang mutu 2 sebanyak 697.937 kg dan ikan cakalang kecil sebanyak 697.117 kg. Jumlah tangkapan ikan cakalang mengalami kenaikan hasil tangkapan mulai bulan Maret sampai bulan November. Jumlah tangkapan paling sedikit adalah pada bulan Januari dan hasil tangkapan terbesar pada bulan Juli, jumlah hasil tangkapan menurun kembali pada bulan Desember sampai dengan Februari. Jumlah hasil perikanan tangkap sangat dipengaruhi oleh kondisi alam dan musim (Talib, 2018). Menurut Nur (2011), fluktuasi jumlah produksi bulanan dipengaruhi oleh kondisi oseanografi yaitu rata-rata suhu permukan laut dan ratarata jumlah klorofil-a di wilayah perairan Samudera Hindia selatan Jawa Timur yang mempengaruhi rata-rata Catch Per Unit Efforts (CPUE). Selama tahun 2005-2009 pada bulan Desember - April, rataan suhu permukaan laut mencapai diatas $27,5^{\circ} \mathrm{C}$ yang menyebabkan rataan konsentrasi klorofil-a menurun dibawah 0,25 mg. . $^{-1}$ dan rataan CPUE juga menurun dibawah 1.000 kg/trip. Variasi kondisi oseanografi ini juga menyimpulkan bahwa wilayah perairan Laut Selatan Jawa memiliki kesuburan tertinggi pada bulan Juli, Agustus, September (musim timur) dan terendah pada bulan Desember, Januari, Februari (musim barat). Pada musim barat wilayah subur lebih terkonsentrasi di bagian barat laut Indonesia yaitu di sekitar Selat Malaka, Laut Natuna, dan Selat Karimata. Berdasarkan hal tersebut diduga musim puncak penangkapan cakalang pada musim barat juga bergeser ke wilayah bagian barat laut Indonesia.

Berdasarkan total jumlah hasil tangkapan ikan cakalang dalam 1 tahun di PPP Pondokdadap diketahui persentase jumlah hasil tangkapan dengan mutu 2 sebanyak 19\% dari total jumlah hasil tangkapan. Hal ini menunjukkan bahwa di PPP Pondokdadap memiliki hasil tangkapan ikan cakalang dengan mutu yang baik. Ikan dikategorikan sebagai ikan segar apabila memiliki nilai organoleptik minimal 7 (BSN, 2006). Kondisi fisik ikan juga sangat berpengaruh terhadap pola dan kecepatan penurunan mutu ikan. Ikan dengan kondisi memar atau terluka 
akan mengalami proses kemunduran mutu yang lebih cepat dibandingkan dengan ikan yang tanpa memiliki cacat fisik. Mutu ikan juga berpengaruh terhadap harga ikan. Pada PPP Pondokdadap ikan dengan mutu 2 memiliki harga yang lebih murah dibandingkan dengan ikan dengan mutu 1. Berdasarkan hasil perhitungan tingkat kehilangan akibat susut mutu (losses) ikan cakalang di PPP Pondokdadap didapatkan rata-rata tingkat losses sebesar 3,23\% dalam 1 tahun.

Kapal penangkap ikan cakalang yang merapat ke dermaga pelabuhan untuk mendaratkan ikan pada umumnya melakukan pembongkaran ikan pada pagi hari atau sore hari untuk menghindari sinar matahari. Waktu yang dibutuhkan untuk melakukan pembongkaran ikan dari satu kapal biasanya sekitar 1-2 jam tergantung jumlah ikan hasil tangkapan. Suhu ikan saat pembongkaran dapat terjaga dibawah $4,4^{\circ} \mathrm{C}$ dikarenakan penggunaan es yang jumlahnya mencukupi. Es merupakan perbekalan yang sangat penting dalam kegiatan penanganan ikan baik di atas kapal maupun setelah pendaratan. Secara umum dapat ditetapkan bahwa untuk mendinginkan $1 \mathrm{~kg}$ ikan dibutuhkan $2 \mathrm{~kg}$ es atau $1: 2$. Penggunaan es saat penyimpanan di palka menunjukkan bahwa jumlah es sudah mencukupi dalam proses penyimpanan hasil tangkapan. Hal ini juga menunjukkan bahwa pada saat pembongkaran ikan masih menerapkan sistem rantai dingin yang baik. Hal yang perlu mendapat perbaikan pada saat pembongkaran ikan adalah kondisi nelayan yang melakukan pembongkaran kurang menerapkan sanitasi dan higiene yang baik, masih banyak yang tidak menggunakan pakaian kerja dan masih ada yang melakukan pembongkaran sambil merokok.

Ikan yang sudah dibeli dari hasil pelelangan di Tempat Pelelangan Ikan diangkut menggunakan kendaraan roda tiga atau kendaraan roda empat ke tempat/gudang supplier ikan. Pada saat pengangkutan, ikan dimasukkan dalam keranjang yang tidak menggunakan es. Saat sampai di gudang, ikan diberi tambahan es balok yang sudah dihancurkan. Hal ini bertujuan untuk mempertahankan suhu ikan. Berdasarkan hasil pengukuran di lapangan, suhu ikan cakalang yang ditangani di gudang pengumpul berkisar antara $5^{\circ} \mathrm{C}$ hingga $7,5^{\circ} \mathrm{C}$. Hasil pengukuran menunjukkan bahwa suhu ikan melebihi ketentuan dari Food and Drug Administration (2011) yang mensyaratkan suhu ikan harus dibawah $4,4^{\circ} \mathrm{C}$. Hal ini terjadi karena pada saat proses pelelangan tidak dilakukan 
penambahan es dan saat pengangkutan juga tidak menggunakan es. Penggunaan es baru dilakukan pada saat ikan sampai di gudang pengumpul namun jumlah es yang digunakan saat penanganan masih belum cukup dibandingkan jumlah maupun berat ikan.

Berdasarkan hasil pengukuran di lapangan diketahui suhu ikan cakalang yang ditangani oleh penjual berkisar antara $7{ }^{\circ} \mathrm{C}$ hingga $13,8{ }^{\circ} \mathrm{C}$. Naiknya suhu ikan dikarenakan penggunaan es yang digunakan oleh penjual masih kurang memadai dan suhu ruangan kios ikan nelayan yang terbuka membuat suhu ruangan langsung terkena sinar matahari. Suhu ikan yang tinggi menunjukkan bahwa penanganan ikan cakalang di kios ikan nelayan belum menerapkan sistem rantai dingin yang baik dan mutu ikan cakalang akan mudah menurun. Tempat kios ikan nelayan secara umum sudah cukup bersih namun sebagian kios penjual masih belum teratur dalam melakukan pembersihan kios masing-masing, terlihat kondisi dinding yang kotor, air bekas cucian dan darah ikan yang tergenang dilantai. Para penjual ikan juga belum memakai pakaian kerja khusus dan para pembeli juga kurang menjaga kebersihan.

Uji organoleptik pada ikan cakalang pada 3 (tiga) tempat yang berbeda yaitu tempat pendaratan ikan, tempat pengumpul ikan/supplier dan kios ikan nelayan menunjukkan bahwa kondisi ikan masih segar dengan nilai minimal 7. Ikan dikategorikan sebagai ikan yang masih dalam keadaan segar apabila hasil penilaian secara organoleptik memiliki nilai minimal 7 (BSN, 2006). Berdasarkan hasil uji organoleptik menunjukkan terdapat perbedaan mutu kesegaran antara ikan di tempat pendaratan ikan dengan ikan di tempat pengumpul ikan/supplier dan kios ikan nelayan walaupun ikan masih tetap dalam kondisi segar. Adanya perbedaan mengenai kondisi kesegaran ikan dimungkinkan karena adanya perbedaan dalam penanganan dan penerapan sistem rantai dingin. Penanganan ikan yang kurang tepat dapat menyebabkan protein yang ada di dalam tubuh ikan dimanfaatkan untuk perkembangbiakan mikroorganisme sehingga mutu ikan akan menurun (Furqan, 2017). Ikan cakalang termasuk jenis ikan pelagis besar yang cepat mengalami penurunan mutu sehingga diperlukan penanganan yang cepat dan tepat (Moeljanto, 1992). 
Penanganan ikan cakalang yang saat ini dilakukan di Tempat Pemasaran Ikan (Kios Ikan Nelayan) PPP Pondokdadap didapatkan kesenjangan sebesar 1,1 dengan tingkat kesesuaian yaitu sebesar 73,2\%, yang berarti penanganan tersebut hampir sesuai dengan standar. Hal-hal yang menyebabkan penanganan belum memenuhi standar diantaranya ruangan belum dilengkapi dengan tanda peringatan dilarang merokok, meludah, makan dan minum yang seharusnya diletakkan di tempat yang mudah dilihat dengan jelas, ruangan pemasaran belum memenuhi persyaratan higiene dan penerapan sistem rantai dingin yang ditunjukkan dengan suhu ruangan yang tidak dalam kondisi dingin dan dinding ruangan semi terbuka yang mempengaruhi kenaikan suhu ruangan dan suhu produk yang dipasarkan, belum mempunyai tempat khusus untuk unit pengendalian keamanan hasil perikanan dan peralatan yang digunakan masih bercampur dengan bahan lain dan tidak disimpan dengan baik. Bongkar muat ikan harus memperhatikan peralatan yang berhubungan dengan produk, tempat bongkar muat dan pekerja harus dalam keadaan bersih, terhindar dari sinar matahari dan menerapkan sistem rantai dingin (Kepmen KP 52A, 2013).

\section{KESIMPULAN}

Kesimpulan pada penelitian ini yaitu: (1) Jumlah ikan cakalang yang didaratkan di PPP Pondokdadap tahun 2018 terdiri dari ikan mutu 1 sebanyak 62\%, ikan mutu 2 sebanyak 19\% dan ikan cakalang kecil sebanyak 19\% dan tingkat losses sebesar 3,23\% selama 1 (satu) tahun; (2) Proses penanganan ikan cakalang di tempat pendaratan ikan, tempat pengumpul ikan dan kios ikan nelayan sudah cukup baik namun masih harus diperbaiki lagi khususnya dari aspek sanitasi dan higene bangunan, karyawan dan peralatan; (3) Tingkat penerapan standar mutu penanganan ikan cakalang di tempat pendaratan ikan rata-rata mencapai 62,5\%, empat pengumpul ikan rata-rata mencapai 67,2\% dan kios ikan nelayan rata-rata mencapai $73,2 \%$. 


\section{DAFTAR PUSTAKA}

Badan Standarisasi Nasional (BSN). 2006. Petunjuk Pengujian Organoleptik dan atau Sensori SNI 01-2346-2006. Jakarta.

DKP Jatim. 2013. Dinas Perikanan dan Kelautan Jawa Timur. Laporan Tahunan Perikanan Tangkap. Surabaya.

Food and Drug Administration (FDA). 2011. Fish and Fishery Products Hazard and Control Guidance Fourth Edition-April 2011. Department of Health and Human Services-USA.

Furqan, A. 2017. Penanganan Hasil Tangkapan Tuna di Pelabuhan Perikanan Pantai Pondokdadap untuk Memenuhi Standar Pasar Ekspor. [Tesis]. Institut Pertanian Bogor. Bogor.

Junianto. 2003. Teknik Penanganan Ikan. Seri Agri Wawasan. Penebar Swadaya. Jakarta.

Moeljanto, R. 1992. Pengawetan dan Pengolahan Hasil Perikanan. Penebar Swadaya. Jakarta.

Nur, AI. 2011. Keberlanjutan Sumberdaya Perikanan Cakalang (Katsuwonus pelamis) di Perairan Zona Ekonomi Eksklusif Indonesia (ZEEI) Samudera Hindia Selatan Jawa Timur [Disertasi]. Sekolah Pasca Sarjana, Institut Pertanian Bogor. Bogor.

Talib, A. 2018. Peluang Dan Tantangan Industri Teknologi Pengolahan Hasil Perikanan Dalam Mendukung Terwujudnya Lumbung Ikan Nasional (LIN) Di Maluku Utara. Jurnal Agribisnis Perikanan Vol. 11: 19-27. 